\title{
Nordic Student Teachers' Views on the Most Efficient Teaching and Learning Methods for Species and Species Identification
}

\author{
Irmeli Palmberg ${ }^{1, *(\mathbb{C})}$, Sirpa Kärkkäinen ${ }^{2} \mathbb{( D}$, Eila Jeronen ${ }^{3}$, Eija Yli-Panula ${ }^{4} \mathbb{C}$ and \\ Christel Persson ${ }^{5}$ D \\ 1 Faculty of Education and Welfare Studies, Åbo Akademi University, Rantakatu 1, FI-65100 Vaasa, Finland \\ 2 School of Applied Educational Science and Teacher Education, Philosophical Faculty, University of Eastern \\ Finland, Yliopistonkatu 2, FI-80100 Joensuu, Finland; sirpa.a.karkkainen@uef.fi \\ 3 Faculty of Education, University of Oulu, Pentti Kaiteran katu 1, FI-90014 Oulu, Finland; eila.jeronen@oulu.fi \\ 4 Faculty of Education, University of Turku, Assistentinkatu 5, FI-20014 Turku, Finland; eija.yli-panula@utu.fi \\ 5 Faculty of Natural Sciences, Kristianstad University, Elmetorpsvägen 15, SE-29188 Kristianstad, Sweden; \\ Christel.persson@hkr.se \\ * Correspondence: irmeli.palmberg@abo.fi
}

Received: 23 August 2019; Accepted: 19 September 2019; Published: 24 September 2019

\begin{abstract}
Teachers need knowledge of species and species identification skills for teaching the structure and function of ecosystems, and the principles of biodiversity and its role in sustainability. The aim of this study is to analyze Nordic student teachers' views on the most efficient methods and strategies to teach and learn species and species identification, and to find some trends about how well their views are reflected in a species identification test. Student teachers in Finland, Norway, and Sweden $(N=426)$ answered a questionnaire consisting of fixed and open-ended questions, and a species identification test. An analysis of variance, Chi-Square, and $t$-test were used for quantitative data and an inductive content analysis for qualitative data. Results showed that outdoor teaching and learning methods are more efficient than indoor methods. The majority of student teachers considered outdoor experiential learning with living organisms as the most efficient teaching and learning method. Student teachers who highlighted outdoor experiential learning and outdoor project work as their most efficient methods received significantly better results in the species identification test than the others. Field trips and fieldwork were emphasized as the most important sources in schools and universities, while the Internet was the most important source among media. The student teachers underlined teachers' expertise in the form of in-depth understanding of subjects and supervising skills for efficient teaching both outdoors and indoors. Therefore, teaching and learning of species and species identification as the practical part of biodiversity and sustainability education is emphasized as an integral part of teacher education programs.
\end{abstract}

Keywords: species knowledge; species identification; biodiversity; sustainability; teaching methods; teaching materials; teacher education; professional development

\section{Introduction}

People are living more and more separate from natural environments, while man's impact on the Earth is greatly increasing. At the same time, knowledge of species and species identification, and interest in nature in an ecological context, have significantly declined [1-3]. People are becoming more and more biologically illiterate [4,5]. It is, however, very important to have knowledge of and interest in species and species identification, for several reasons. For example, without knowledge of species it is impossible to understand the structure and function of ecosystems (life-supporting 
systems on the Earth), and the principles of biodiversity and its role in sustainability $[3,6,7]$. The importance of species, biodiversity and sustainability are continuously emphasized also in the latest school curricula in the Nordic countries [8-11], and therefore, these issues should also be included in teacher education programs for primary-school teachers. Such is not, however, the situation yet [12-15], although also student teachers in several countries have clearly expressed the importance of species and species identification in general and especially in their education $[1,7,16,17]$. Even though student teachers named school and university among their most important sources of information about species, their ability to identify very common species was still very low [18].

Could, in fact, one of the factors that affect the development of students' identification and observation skills be the inefficiency of the actual teaching and learning methods? In this study we ask student teachers' opinions of how they have learnt and learn about species and species identification and how they are planning to teach these subjects in interesting and efficient ways. The aim of this study is therefore to analyze student teachers' views on the most efficient methods to teach and learn species and species identification and how the views are reflected in their identification test. Teachers' views are namely factors affecting their planning and teaching of biodiversity and sustainability $[19,20]$ and the actual student teachers are future teachers who already studied and learnt several teaching strategies during their study period.

By 'efficiency' in teaching and learning methods in this context we mean approaches which in a short time clearly increase knowledge and skills in the observation and identification of species, but also higher-order cognitive skills, such as sustainability thinking, as requested, e.g., by Zoller [21]. By 'teaching and learning methods' we mean diverse methods, diverse materials and sources which, according to previous research, are, or could be, used especially in teaching about species and species identification. By 'species identification' we mean skills for identifying organisms on a species level but also identifying special characteristics of organisms and their systematic groups, and thereby also obtaining knowledge of the role of species in ecosystems and sustainability. Sustainability is a complex concept including ecological, economic, and social dimensions with several interrelated aspects [22], but in the context of species and species identification we focus on ecological dimensions of sustainability and sustainability education. As a theoretical background to our research questions and questionnaire we describe some general aspects concerning teaching and learning for sustainability, involving also aspects for teaching and learning for species and species identification.

\section{Literature Review}

\subsection{Teaching and Learning for Sustainability}

The purpose of all teaching is to teach for understanding. This requires teachers to organize thought-demanding activities which challenge learners to apply and extend their prior knowledge. It also makes high demands on teachers' subject matter knowledge and their in-depth understanding of subjects [23]. Therefore, based on Shulman's initial concept [24], research on the professional development of teachers has mainly focused on three domains of professional knowledge: content knowledge (CK), pedagogical content knowledge (PCK), and pedagogical knowledge (PK) [25-29].

The focus in this study is on PCK, which is often used to explain the type of in-depth understanding needed to teach efficiently [30]. What should teachers' PCK contain in the case of teaching and learning about species and species identification, in the context of biodiversity and sustainability education? As many of the professional skills, especially those in sustainability, overlap with personal development and growth, teaching and learning should engage heads, hands and hearts in order to achieve transformative learning [31]. Transformative learning is interpreted as a quality of learning that is deeply engaging, and touches and changes deep levels of values and beliefs through a process of realization and recognition [32]. A transformative perspective is valuable also in science education, where teachers' science PCK is often limited [25], and especially when the goal is to motivate students in qualities such as values, attitudes, and consciousness in order to promote deep engagement and 
understanding [33]. Education promoting sustainability aspects, and thereby also education about species and species identification, is strongly based on values, attitudes and experiences $[31,34,35]$. According to the experiential learning theory [36], students learn more efficiently by 'doing' than by 'listening'. The approach of active teaching and learning, for example fieldwork and field trips which include problem-based activities and learning-by-doing, significantly improved students' interest, knowledge, attitudes and behavior, concerning sustainability [37]. Connections to everyday life and real-life learning, being in the environment and having sensory engagement are revealed to be additional factors improving these aspects [38,39].

\subsection{Teaching and Learning of Species and Species Identification}

What kind of teaching methods and materials could best promote interest in studying and learning about species and species identification? In the Nordic countries, teaching and learning of species and species identification are mainly a part of ecological and environmental goals in biology or science education [7]. They also form an important part of teaching and learning about biodiversity and sustainability in several countries $[3,35,40]$. This involves many alternative methods, materials, learning strategies and situational factors.

Research indicates that there is a positive relationship between outdoor fieldwork and students' development of knowledge about and attitudes toward species [41-43]. According to university teachers, the best and most efficient teaching and learning method for identification skills is to practice in nature [1]. Based on observation studies, student interviews and teacher interviews, the most engaging, efficient, and enduring learning experiences in the context of learning in natural environments, occurred through experience-based rather than teacher-directed strategies [38]. According to several researchers, fieldwork in a natural environment including hands-on experiences develops students' understanding of taxonomies and the anatomy of organisms [42,44-46]. Fieldwork also increases students' attainment, improves their cognitive learning [47,48], and develops their observation skills [49]. 'Experiential learning' is authentic, first-hand, sensory-based learning through a specific experience [50]. The importance of first-hand experiences of the natural environment has therefore been emphasized in several studies around the world [42,47,51-53]. However, teacher education programs seldom include practical methods for fieldwork or outdoor education [54,55].

Fieldwork and field trips in a natural environment often include identification of organisms on species level and of their place in ecosystems in a bigger picture. There exist, however, only some minor studies about how people usually identify organisms, what characteristics they observe and what strategies they use. For example, young children identified animals mainly by direct observation of some anatomical features and only seldom by behavior or habitat [56], while student teachers identified birds by their nesting habitat, coloring and markings, shape and size of different parts of the body as well as their special behaviors [57]. Regarding plants, some students identified them only by matching pictures of plants with living plants [58]. In addition to colors, smell, touch and taste of plants, some students and also teachers focused separately on details in leaves, flowers, seeds, berries, fruits and cones [1]. Research does not, however, reveal any characteristics which are successfully used in teaching and learning identification skills, neither teachers' views on their mostly used characteristics.

Despite living animals and plants, teaching and learning materials have included for example stuffed animals, dried plants, plastic models, identification books with photos or drawings, dichotomous identification keys, signs and tracks of animals, videos and animations [3,59]. Additionally, identification of species has included the use of the Internet [60], Internet-based taxonomic resources [57] or web-based key characteristics of species [61]. According to Randler [62], there is a positive relationship between different kinds of animal-related activities and species knowledge. People who used identification books also had significantly higher scores in knowledge than other participants. The Internet, on the contrary, was not considered an optimal source for identification of unfamiliar species in Randler's study [62]. 
How and where do people learn species and species identification? What kind of factors could develop their identification skills and make identification tempting and successful? These are interesting questions in an educational context, particularly because school curricula in many countries still emphasize the importance of species and species identification as part of understanding biodiversity and sustainability. As far as we know, however, there are no comparative studies available about the efficiency of different teaching and learning methods and strategies for species identification, neither about teachers' or student teachers' views on teaching in this context. Therefore, in this study we focus on student teachers' views on methods and strategies, and in doing so gain implications and suggestions for teacher education.

\section{The Aim of the Study and Research Questions}

This is a part of a comprehensive Nordic study of student teachers' views on species, biodiversity and sustainability. The main aim of this study is to analyze Nordic student teachers' views on the most efficient methods and strategies to teach and learn species and species identification. An additional aim is to find some trends about how well their views are reflected in the species identification test. The research questions are:

1. What kind of views do the student teachers express about the most efficient methods for teaching and learning species and species identification?

2. What kind of views do the student teachers express about the most efficient materials and sources for teaching and learning species and species identification?

3. What kind of characteristics and strategies do the student teachers prefer when they identify species?

4. Do student teachers' views on efficiency reflect their results in the species identification test?

The Nordic results can be utilized for teacher education programs worldwide, because knowledge of species and species identification is equally important for people's nature experiences and their positive environmental attitudes, as well as in biodiversity and sustainability, all around the world, as emphasized in several research reports $[3,6,17,35,40,44-46]$.

\section{Materials and Methods}

Second- to fourth-year student teachers in Finland, Norway, and Sweden $(\mathrm{N}=426)$ participated in the survey as volunteers. Student teachers are university students who study education as their main subject in order to become primary-school teachers. They had taken the obligatory course/courses in biology or science (including, e.g., teaching methods) at least half a year before taking part in the survey. The majority ( $82 \%$ ) were women, $65 \%$ were under 25 years old, while $24 \%$ were $25-35$, and $11 \%$ were over 35 . The sample thus represented the typical group of student teachers by gender, age, and completed obligatory studies in biology or science in the Nordic countries. The majority of the student teachers $(64 \%)$ lived in an urban environment, i.e., towns or cities. More than a half of them $(66 \%)$ reported very high or high interest in nature.

The survey consisted of three parts: Questions about the student teachers' background, a species identification test, and a comprehensive questionnaire with fixed, multiple-choice, and open questions (see Supplementary Materials). A research group representing the participating countries developed and pre-tested the questionnaire (18). All material was collected during one single session (approximately $45 \mathrm{~min}$ ), during or immediately after a lecture in teacher education programs of each participating unit, administered by a local researcher. For this study, six questions from the questionnaire were selected to get answers to the current research questions. The six questions concerned student teachers' views on the efficiency of methods, and the kind of materials, sources and characteristics for teaching and learning species and species identification that they used. All the fixed alternatives were based on recent research results (as described in the theory part) and on our own experience of teaching and learning in this context. 
The student teachers were asked to tick the (1-3) most efficient methods out of 18 alternatives, the (1-3) most efficient materials out of nine alternatives and the three most important sources out of seven alternatives. If they ticked 'school' or 'university', they were further asked to tick their most important source out of the alternatives 'teachers', 'learning materials', 'field trips and fieldwork', and 'species identification in the classroom'. If they ticked 'media', they were asked to tick their most important source out of the alternatives 'newspapers', 'nature journals', 'other journals', 'television', 'Internet', 'social media (Facebook, Twitter, etc.)'. They were also asked to tick the (1-3) most important characteristics of plants and animals in photos and in nature when identifying species. The fixed alternatives in this question varied between 5 and 13. All six questions also had an alternative 'others' and a request to the student teachers to explain or argument for their answer, except for the question of used characteristics.

A combination of quantitative and qualitative methods was used. The quantitative data was coded and analyzed using SPSS Version 25. In addition to background factors (gender, age, residency, interest in nature), the student teachers' answers about their most efficient teaching and learning methods, materials, sources and strategies for species identification, were compared with their results from the species identification test consisting of 18 common species (9 plants and 9 animals). For practical reasons, the results from the species identification test were clustered into three groups: $0-6,7-12$, and 13-18 correctly identified species, or into two groups: 0-9 plant and 0-9 animal species correctly identified. The data was frequency data, verified for normal distribution and descriptive analyses made. Analysis of one-way variance (ANOVA), Chi-Square Tests of independence (cross-tabulation) or independent samples $t$-test were used to compare differences between groups and to test possible relationships or significances of differences. After the test of homogeneity of variance (Levene's test), Tukey's post hoc was further used to identify pairs with significant differences.

The open-ended answers were transcribed and analyzed through inductive content analysis [63], categorized according to the given alternatives in the questionnaire, and the most describing quotations were given to exemplify frequently given answers from the most popular categories. The quotations of true translations from Finnish, Norwegian, or Swedish were marked with four-digit numbers (SPSS-id) to guarantee anonymity. Reliability and validity were established through the pre-test of the questionnaire (18), by three researchers analyzing and discussing the open-ended answers, and through the use of true quotations from the original answers.

\section{Results}

In this study, Nordic student teachers' views on the most efficient methods, materials and strategies to teach and learn species and species identification, as well as the most important characteristics they used in the identification of plant and animal species, were analyzed. Regarding the student teachers' answers about their (1-3) most efficient methods out of the 18 alternatives, only answers containing the correct number of ticked alternatives $(1-3)$ were accepted $(n=204)$. The remaining student teachers $(n=220)$ had not followed the instruction and ticked 4-11 alternatives instead of 1-3. Every single alternative was ticked by at least some of the student teachers, a fact that shows how wide the range of efficient methods is and how differently methods can appeal to different individuals. The explanations given by the student teachers also reveal how difficult it is to rank methods using efficiency as a criterion. Moreover, several of the student teachers had clearly misunderstood what a given method was about, and that the question concerned only methods specifically for teaching and learning species and species identification. Answers about the most efficient materials and the most important sources (e.g., field trip and fieldwork) overlapped in the student teachers' answers, and these are therefore described here together. Some of the selected quotations included several aspects, while others focused on only one aspect. 


\subsection{Student Teachers' Views on the Most Efficient Teaching and Learning Methods}

'Outdoor experiential learning' was ticked by a clear majority of the student teachers (64.7\%) as one of the most efficient teaching and learning methods for species and species identification out of the 18 alternatives (see Figure 1). The following most frequently ticked alternatives were 'outdoor project work' (29.9\%), 'indoor experiential learning (28.9\%), 'outdoor teacher-centered education' $(26 \%)$, and 'indoor teacher-centered education' (19.1\%). Outdoor methods were always more preferred than the corresponding indoor methods, except for the 'traditional group work', which was preferred indoors by $9.8 \%$ and outdoors by $6.4 \%$ of the student teachers. In contrast, 'group inquiry' outdoors was ticked by a somewhat large number of student teachers than indoors ( $11.3 \%$ and $9.3 \%$, respectively). Student-centered methods were more emphasized than teacher-centered, although the teacher's role as an instructor, a knowledge base or a supervisor was pointed out also in other than teacher-centered methods. Learning together and having expert groups through 'cooperative learning' outdoors were ticked by $13.7 \%$ and indoors by $11.8 \%$ of the student teachers. Methods ticked as efficient by at least one of ten student teachers were: 'experimental learning' outdoors $(12.3 \%)$ and indoors $(10.3 \%)$, as well as 'indoor project work' (12.3\%), while for example 'problem-based learning' outdoors and indoors were ticked only by a few student teachers ( $5.4 \%$ and $1.5 \%$, respectively). The alternative 'others' (indoors $7.4 \%$ and outdoors $4.9 \%$ ) included learning by using various sources of information, independent learning, making observations and drawings, taking photos, collecting plant species for a herbarium, learning through games, participating in excursions and fieldwork.

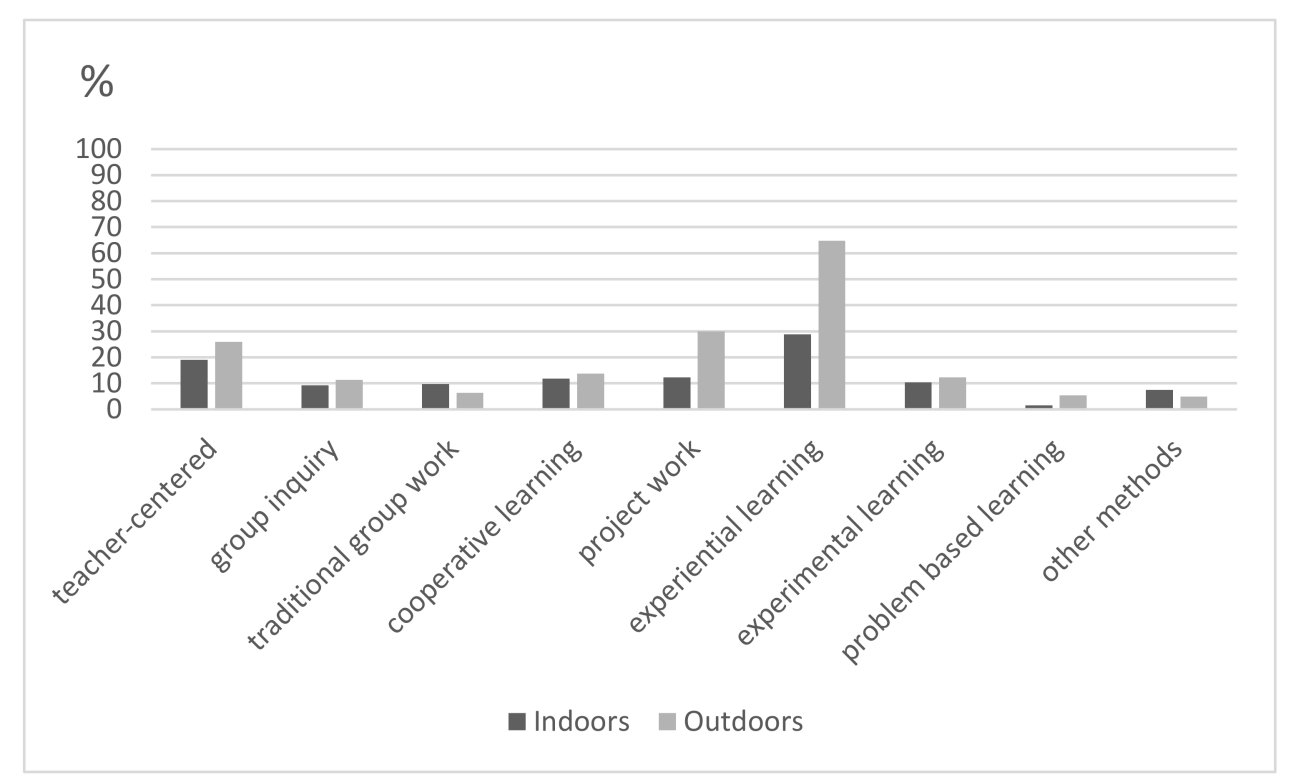

Figure 1. The most efficient teaching methods for identification of species, ticked by the student teachers $(n=204)$ as their 1-3 most efficient methods (the alternative 'others' included, e.g., playing games, participating in excursions and fieldwork, making observations and drawings, collecting plant species for a herbarium).

Do the student teachers' opinions about the most efficient method also reflect their results in the species identification test? The only significant difference between any two groups was between student teachers who emphasized outdoor project work and those who did not $[t(123)=2.364, p=0.020]$. Student teachers who emphasized both outdoor experiential learning and outdoor project work as their most efficient methods, also received significantly better results than the others, but the effect size was small $\left[F(1,202)=5.445, p=0.021, \eta^{2}=0.026\right]$. Furthermore, student teachers who emphasized outdoor methods received better results when identifying plant species than those who preferred indoor methods $\left(\chi^{2}=4.916, \mathrm{df} 1, p=0.027\right)$. These results are, however, only indicative, because the 
student teachers ticked and explained their alternatives from three different perspectives instead of one, i.e., how they themselves have learnt species.

There was also a relationship between different levels of interest in nature and the student teachers' opinions about their most efficient teaching and learning methods. Student teachers who had a high or very high level of interest in nature had a slightly more positive opinion about outdoor experiential learning and outdoor project work than the other student teachers $\left(\chi^{2}=8.263, \mathrm{df} 2, p=0.016\right)$. More specifically, student teachers who had a very high level of interest preferred outdoor project work $\left(\chi^{2}=6.823\right.$, df $\left.2, p=0.033\right)$ more often and outdoor teacher-centered learning less often $\left(\chi^{2}=6.060\right.$, df $2, p=0.048)$ than the others. Student teachers who were not interested in nature preferred outdoor experiential learning as their most efficient method $\left(\chi^{2}=7.453\right.$, df $\left.2, p=0.024\right)$ more often than the others.

There were also differences in the student teachers' opinions about the efficient methods regarding their residency, gender and age. Student teachers who had lived in urban areas preferred indoor methods significantly more often than outdoor methods $\left(\chi^{2}=10.674, \mathrm{df} 1, p=0.001\right)$, whereas those who had lived in rural areas preferred outdoor methods $\left(\chi^{2}=7.087, \mathrm{df} 1, p=0.008\right)$. More specifically, the urban student teachers preferred indoor cooperative learning more often than the rural ones $\left(\chi^{2}=5.693\right.$, df $\left.1, p=0.015\right)$, whereas the rural ones preferred outdoor group inquiry significantly more often than the urban ones $\left(\chi^{2}=17.474, \mathrm{df} 1, p=0.000\right)$. Outdoor methods were preferred more often by women than by men $\left(\chi^{2}=8.897\right.$, df $\left.1, p=0003\right)$, whereas age did not result in any significant differences, except that student teachers in age group 25-35 preferred outdoor experiential learning more often than the others $\left(\chi^{2}=6.818, \mathrm{df} 2, p=0.033\right)$.

\section{Student Teachers' Explanations}

The student teachers were asked to explain why they think these methods are their 1-3 most efficient when teaching and learning species and species identification. They explained their views from three different perspectives: how they themselves have learnt (or not learnt), how they themselves would like to teach or what they (without any personal experience) considered could be the most efficient methods.

'Outdoor experiential learning' was explained by the student teachers as the best way to learn through concrete experiences and the use of several senses for observations. Additionally, outdoor environment was described as an authentic, real environment, which enables people's hands-on activities and promotes their long-term memory. Most of them expressed the efficiency of outdoor experiential learning in the same way as in the following examples: "Concrete observations, which are based on experiences and several senses, leave a permanent memory, long-term memory" (1030) or "Experiential learning make it easier to learn and remember different species, because through it you get directly into the core of the matter. When you use vision, hearing and at least smell, you learn in several different ways"(1069). The student teachers also pointed out that experiential learning gives more value and meaning to the studied issues because of personal experiences. Some of the student teachers underlined the role of teachers also in outdoor learning: "The best way of learning species is in the terrain, where both teacher and students find different plants, animals, insects, because then it is easier to identify the species. Together we see and explore and identify various species"(3033).

'Outdoor project work' was often mentioned together with outdoor experiential learning. The efficiency of these was explained through active participation and contact with nature, but also by teacher guidance: "A learner can participate on their own, experience and make observations under guidance. Real contact with nature creates a personal relationship with it and stays in your memory" (1183) and "The presence of a teacher as an expert is good in project work"(1218). The efficiency of project work depended on "learning-by-doing" (2038), and "thrash out something when you yourself look for information and you also remember it better than when a teacher just tells you something"(2012). 
'Teacher-centered' learning outdoors or indoors as the most efficient method rested on encouraging teachers as experts with solid subject knowledge and supervising skills: "At least I learn the best, when the teacher guides my attention to the most important characteristics" (1136) or "Under the teacher's guidance we immediately learn the correct names and learn to focus on the right things regarding species identification"(1198). Teacher-centered could also be the only method the student teacher had experience of, or, as an older student teacher expressed it: "When I was at school, teacher-centered was by far the most dominating teaching method. About the others we probably had not heard at that time" (1182).

'Cooperative learning' outdoors or indoors was highlighted as one of the student teachers' most efficient methods, due to the opportunity to experience learning issues together with their peers and also the demand of a high level of their own knowledge in order to be able to teach it further to others in the group. Some of them expressed it in following ways: "Having cooperative learning outdoors means that we are close to nature, experience things together with people your age. The responsibility to teach the others improves your own learning" (1141) and "I think learning species works the best through practical experience and when you have to take it in so well that you can teach it to others" (1156) and "Demonstrations of species by learners are performed using their own, more easily understandable terminology"(1140).

'Experimental learning' outdoors and indoors were chosen as one of the most efficient teaching and learning methods because of the opportunity to practice and study things more in depth: "Experiments and experiences are good methods, because then you really investigate in depth" (1192) or "I myself learn the best by doing and studying things" (1139) or "To study living plants is very important instead of only pictures. To be in nature strengthens learning"(1200). The importance of 'group inquiry' was pointed out both before and after experiments, but also as an efficient method in itself: "In the classroom you can start exploring things by discussing together about the ways in which you can identify different species" (1076) and "In group inquiry both the teacher and the learners participate in the discussion and thereby gather more facts for identification of species"(1108), as well as, "you can ask students about their observations on organisms and after that the teacher can complete the observations-in-depth learning and all important things will be taken into account"(1075). 'Traditional group work' was motivated by: "You can use several learners' knowledge"(1083), but it also got negative comments: "Regarding group work I felt that time was splurged to everything irrelevant"(1182). The few student teachers who ticked 'problem-based learning' outdoors or indoors as one of their most efficient methods defined it precisely as a method that enabled in-depth learning.

\subsection{Student Teachers' Views on the Most Efficient Materials and Sources for Teaching and Learning}

As a natural consequence of the fact that outdoor methods were emphasized as efficient teaching and learning methods for species identification, living organisms were pointed out as an important source. A clear majority, about $85 \%$ of the student teachers, ticked living plants as one of their most efficient teaching materials for teaching and learning species and species identification, followed by living animals (57\%) (see Figure 2). The third and fourth most emphasized materials were photos and drawings (41.8\%) and stuffed animals (34.8\%). CD/DVD was ticked by $23.4 \%$, the Internet by $21 \%$ and books by $19.1 \%$ of the student teachers. Furthermore, $8.7 \%$ of the student teachers considered dried plants to be important for teaching and learning species and species identification. Magazines were the least ticked, only by $1.4 \%$ of student teachers. The alternative 'others' $(4.5 \%)$ included e.g., films (not ticked as DVD), TV-nature programs, computer games and programs, and a combination of all given alternatives.

When all emphasized materials were compared with the results in the identification test, only the use of living plants resulted in significantly better results. Student teachers who emphasized living plants as their most efficient material received significantly better results in identification of plant species than those who did not $[t(81)=2.603, p=0.011]$. The women ticked living plants significantly more often than the men $\left(\chi^{2}=16.069, \mathrm{df} 1, p=0.000\right)$. 


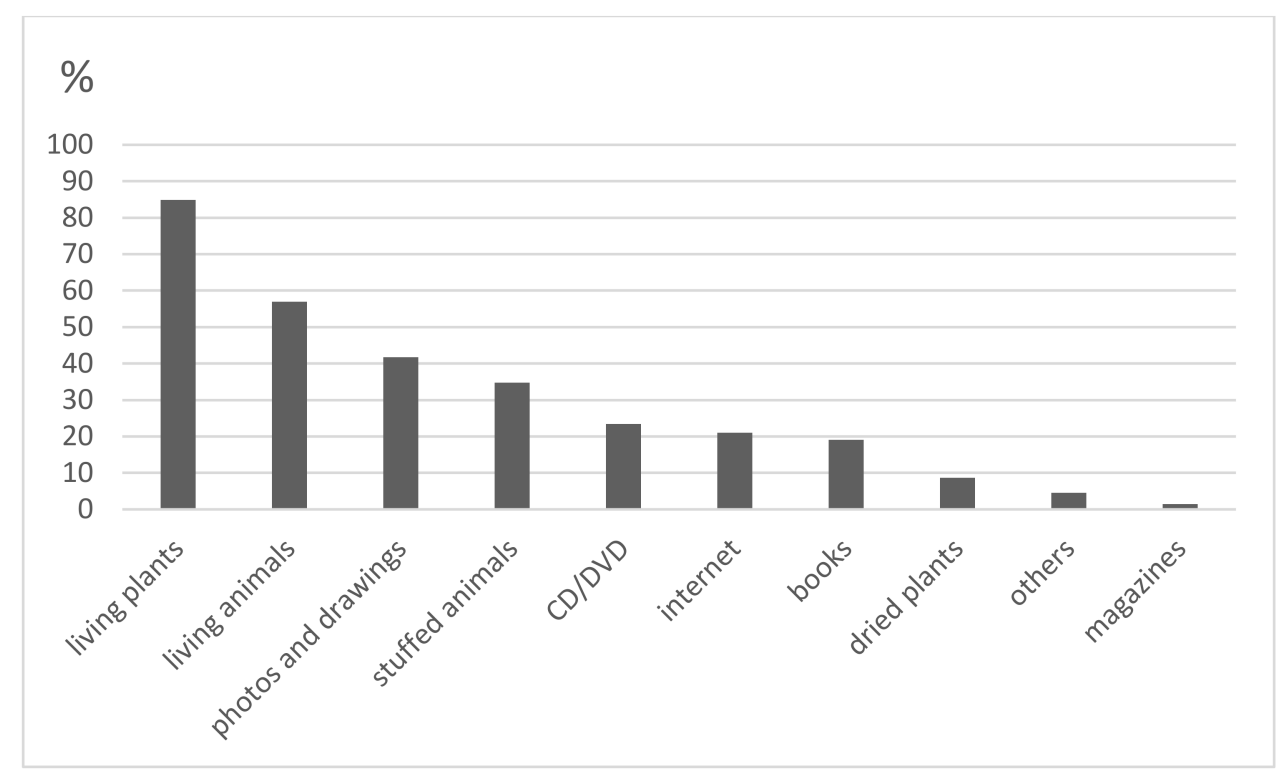

Figure 2. The most efficient teaching materials for identification of species, ticked by the student teachers $(n=423)$ as their $1-3$ most efficient materials (the alternative 'others' included, e.g., films, TV-programs and computer games).

When the student teachers were asked to tick their 1-3 most important sources for information of species out of the seven alternatives, more than half of them ticked 'school' (66.5\%), 'media' (64.4\%) and 'family' (56.5\%), while 'university' was ranked by $45.1 \%$ of them (see Figure 3). About a quarter of them $(24.2 \%)$ had 'hobbies' as a source, connected to plant and animal consciousness. Several student teachers considered obtaining information also from their friends $(16.9 \%)$ and other sources $(16.9 \%)$. The category 'others' included mostly books and films of different kinds.

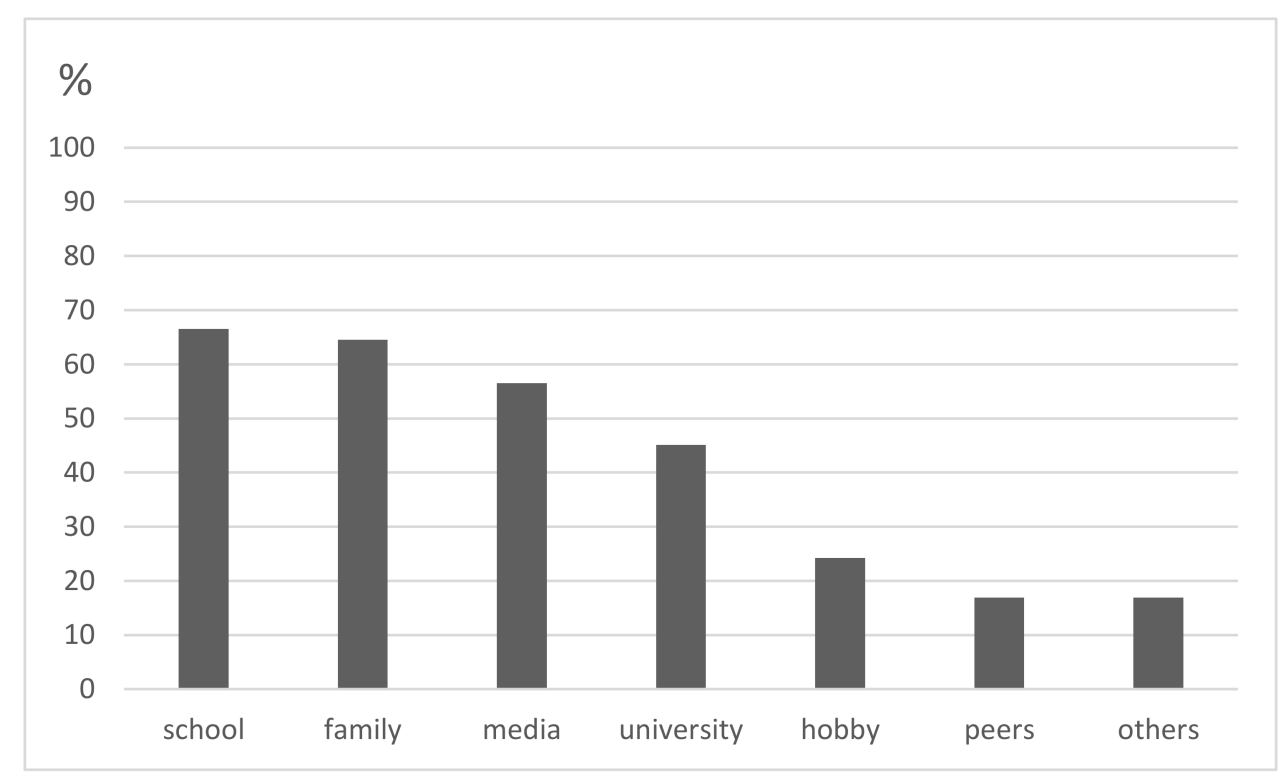

Figure 3. The most important sources of information about animal and plant species, ranked by the student teachers $(n=421)$ as their three most important sources (the category 'others' includes mostly books and films).

Student teachers who had ticked 'school' or 'university' as one of their three most important sources $(n=256)$, were further asked to specify the most important source out of the four alternatives. 'Field trips and fieldwork' were ranked as the most important source by $40.6 \%$, 'learning materials' 
by $34.4 \%$, 'teachers' by $14.5 \%$ and 'species identification in the classroom' by $10.5 \%$ of the student teachers. Significant differences were found when comparing student teachers' sources used for species identification with their results from the identification test $[F(3,169)=6.942, p=0.000]$. More specifically, student teachers who ticked 'field trips and fieldwork' as the most important source received significantly better results than those who ticked 'teachers' $(p=0.000)$. Additionally, student teachers who ticked 'learning materials' as their most important source received significantly better results than those who 'ticked teachers' $(p=0.010)$.

In the same way, student teachers who had ticked 'media' as one of their three most important sources $(n=215)$, were further asked to specify their most important source out of the five alternatives. 'Internet' was ranked by $47.9 \%$ and 'television' by $42.3 \%$ of them, while both 'nature journals' and 'newspapers' were ranked by $4.7 \%$. 'Other journals' were ranked by $0.5 \%$ of the student teachers. No significant difference was found between the used source and the test results, but the men ticked the Internet significantly more often than the women $\left(\chi^{2}=12.707, \mathrm{df} 1, p=0.000\right)$.

\section{Student Teachers' Explanations}

The student teachers explained that living plants and living animals are their most efficient materials for species identification mostly through observations in a real habitat. This often coincided with their answers about their most important sources (field trips and fieldwork) and their most efficient learning and teaching methods (outdoor experiential learning). Furthermore, they pointed out the opportunity to use many different senses outdoors, which motivates learning and increases one's interest in species. Field trips and fieldwork are efficient sources, "because then you are in the plants' and animals' own habitat and everything can be experienced and studied through several senses" (1106) and because "you can experience plants or animals for real; this motivates learning"(1021), "this is [in other words] how you gain practical knowledge, which is kept in mind the best"(1007), and this knowledge can be used later in corresponding environments: "you remember them [species] better when you see a similar environment again"(1054). One of the student teachers answered the question about the most important source for species identification in this way: "I would like to answer 'fieldwork', but we have used it very seldom as a working method, so my own knowledge is based on different kinds of pictures, which I have then combined with what I've seen in nature"(1040).

The student teachers also stated that good learning materials (especially books, textbooks, teacher-produced materials and nature documents in media) support learning through their clear pictures (photos and drawings), clearly-labeled characteristics, sounds, and good descriptions of species. One of the student teachers, one among many others with a similar opinion, explained: "Learning material is a broad concept for me including textbooks and the material produced by the teacher; the pictures and information in these are good sources of information"(1078), while another also pointed out "the opportunity to expand their knowledge also in their leisure time"(1030). "Through books and pictures or looking at species [during excursions or fieldwork]—that's the way I learn the best"(3058).

Some student teachers considered dried plants to be useful, because "collecting plants as homework and the use of dried plant collections was really educational and memorable"(1062). The use of stuffed or other kind of dead animals was efficient, because "they are easy to use during species identification in the classroom"(2008). High quality nature documents and teaching programs on DVD and the Internet (which was an alternative both in materials and sources), or on TV are good sources according to several student teachers, because "moving pictures and presentations of habitats help to perceive the big picture"(1145). In addition, nature programs are "visually stimulating, esthetic and dramatic"(1025). The student teachers also use nature journals or the Internet to find "a lot of information about different species and their systematics" (3014) or to obtain "articles which go deeper into issues about species and their habitat" (2008). In addition to that "The internet is easy to use"(1009), several of them had a very high trust in the Internet as their best source: "you can find everything there"(1010), “ ... and so 
quickly"(2088), or "when I want to find knowledge e.g., for a species identification test, the internet is in my mind the best and most multifaceted source"(1079).

Teachers as important sources were described by some student teachers as "[people] who inform and choose the material"(2115), "are creative and use concrete material" (2071)and "have good professional knowledge, especially subject knowledge, and are therefore able to inspire and motivate, and stimulate curiosity"(3063). The teacher's role as a supervisor was also emphasized in all outdoor education, and for species identification in the classroom: "Species identification in the classroom under the guidance of the teacher offers opportunities to point out the most important characteristics of species. I also prefer listening to the teacher speaking rather than reading about the same thing in a book by myself"(1075).

Student teachers who ticked peers as their most important source of information at the same time emphasized traditional group work or cooperative learning both in the classroom and outdoors. One of them explained it in the following way: "It's nice to work in a group, to share my own and the other group members' observations and experiences; it's educative and helps me to remember things better" (1182).

\subsection{Student Teachers' Preferences for Characteristics When Identifying Species}

Because the student teachers ranked living plants and animals, but also pictures and drawings, as their most important sources for identifying species, they were also asked how they usually identify organisms, what characteristics they observe and what strategies they use, by ticking their (1-3) most important characteristics in photos and in nature. Regarding plants in photos, the student teachers ticked 'color' (84.9\%) and 'flowers' (81.6\%), followed by 'leaves' (81.6\%) and 'forms' $(52.5 \%)$. The corresponding strategies in nature were almost in the same order: 'flowers' $(72.5 \%)$, 'color' $(70.6 \%)$, 'leaves' (52.5\%) and 'forms' (40.9\%), but their frequencies were more spread out, because there were more alternatives to tick when identifying plants in nature (smell, touch, movement and taste) than in photos. In addition, the plants' habitat was used as a strategy more often in nature $(26.1 \%)$ than in photos $(10.9 \%)$. As other alternatives, the student teachers had stems or the actual season in nature when the observation was made.

The most important characteristics when identifying animals in photos were 'form' (88.7\%) and 'color' (86.4\%), followed by 'size' (61.9\% and 'habitat' (24.9\%). Animals in nature were observed by 'form' (74.6\%), 'size' (71.8\%), 'color' (68.7\%) and 'habitat' (27.1\%), but also characteristics which were possible only in nature, such as 'sound' $(32.7 \%)$, 'movement' $(21.9 \%)$ and 'touch' $(1.4 \%)$. As other alternatives, the student teachers had special patterns (e.g., in wings or fur), tracks, feces and different body parts.

Significantly better results in the species identification test were found among those student teachers who used flowers in photos $\left(\chi^{2}=10.076, \mathrm{df} 2, p=0.006\right)$ or in nature $\left(\chi^{2}=20.511\right.$, df 2 , $p=0.000)$ as the most important characteristics of plants. Additionally, student teachers who used leaves of plants as a characteristics to identify them in nature, received significantly better results in the test than the others $\left(\chi^{2}=6.352, \mathrm{df} 2, p=0.000\right)$. No significant test results were found regarding the other characteristics of plants, while only student teacher who emphasized movement of animals in nature received slightly better results than the others $\left(\chi^{2}=6.125, \mathrm{df} 2, p=0.047\right)$. No significant gender differences were found regarding the student teachers' most important characteristics or strategies.

\section{Concluding Discussion}

Knowledge of species and species identification are fundamental prerequisites of people's understanding of biodiversity, ecosystems and ecological sustainability $[3,6,7]$. Previous results about teachers' and student teachers' significantly declined knowledge of species and species identification and their declined interest in nature in an ecological context [1-3] raised the question how we should teach species and species identification in a more tempting and efficient way than we have done so far. The future in mind, we decided to ask student teachers what they considered as their most efficient 
methods to teach and learn species and species identification. We also decided to analyze how well their views were reflected in the species identification test. Their views, together with previous research, are then used as basis for suggestions how to develop teaching of species and species identification in schools and teacher education. The main results are discussed in order to highlight several implications for teacher education and for teachers' professional development in the context of biodiversity and sustainability education.

\subsection{Outdoor Experiential Learning and Outdoor Project Work with Living Plants and Animals}

The first and most purposeful result is that the majority of the student teachers clearly considered outdoor experiential learning as the most efficient teaching and learning method for species and species identification. According to Kolb [36], experiences involve integrating functions of thinking, feeling, perceiving and behaving in the learning process. Knowledge is then created through the transformation of experience, also when connected to sustainability [25]. Congruent with previous research $[38,64]$, the student teachers find that outdoor experiences increase their knowledge, to foster them for positive attitudes toward species, and also to promote their long-term memory. They appreciated opportunities and challenges, which were also emphasized in some previous results. They highlighted for example the opportunity to use several senses for observations (as also pointed out by Beery and Jørgensen [65]), to make first-hand personal experiences (as in Behrendt and Franklin [50] and Palmberg and Kuru [53]) and to have hands-on activities in a real environment with living plants and animals (as emphasized by Morag and Tal [44], Scott et al. [45], Tal et al. [46]). According to Pugh et al. [33] and Rickinson et al. [39], these are thus the most important factors promoting connectedness, deep engagement and understanding of environmental issues. The student teachers also pointed out that outdoor experiential learning gives more value and meaning to the studied issues, a view to be taken into account when making learning about species more interesting and motivating.

A second important result was that outdoor methods were shown to be more efficient than indoor methods (especially in identification of plant species), which supports previous research about the importance of outdoor teaching $[39,41]$. Notable is also that the urban student teachers in this study preferred indoor methods significantly more often than outdoor methods, whereas the rural student teachers preferred outdoor methods. This is in contrast with previous research results, where urban students experienced outdoor learning as something "exotic" and the rural ones as everyday life [66,67]. The majority's opinion about outdoor experiential learning as the most efficient method did not alone correspond to better results in the identification test, whereas the second most emphasized method, outdoor project work, did. Outdoor experiential learning was, however, often emphasized together with outdoor project work. Student teachers who emphasized both outdoor experiential learning and outdoor project work as their most efficient methods, also received significantly better results in the species identification test than the others. The efficiency of outdoor project work was explained through active participation and contact with nature, but also by teacher guidance. The fact that several student teachers pointed out the importance of teachers' skills for guidance outdoors is interesting regarding their own professional development.

According to previous results $[41,68,69]$, there is a positive correlation between the frequency of contact with nature and species knowledge. The more often people made nature trips, the more knowledge of species they gained. The student teachers' high or very high interest in nature also explained their somewhat more positive view about outdoor experiential learning than that of the others, while it is more difficult to understand why student teachers who were not interested in nature preferred outdoor experiential learning significantly more often than the others. More research about reasons is required, but according to our results outdoor experiences could be a starting point for directing student teachers' interest also into other things than their own sense of feeling good.

The student teachers emphasized living organisms as their most efficient material for teaching and learning species and species identification, mostly through observations in their real habitat. This prevalence of outdoor observations and difficulties to observe moving animals is a good explanation 
why the great majority of the student teachers emphasized living plants before living animals, in contrast to several previous studies where living animals were considered more interesting $[18,43,70]$. The women valued living plants significantly more than the men and according to previous results $[1,69]$ they also received better results in plant identification. Living animals in the classroom are, however, recommended as material in order to get a deeper knowledge of the animals' external characteristics and behavior, but especially as a motivational factor [62,71]. The use of living plants was the only material resulting in significantly better results in the identification test. There are no previous results about efficient characteristics in species identification. In this study, the mostly used characteristics in identification of plants were flowers, colors and leaves, but only the use of flowers and leaves gave significantly better results. The mostly used characteristics in identification of animals in turn were form, size and color, but only the use of movement gave significantly better test result.

Experiential learning and project work are often organized in connection with field trips and fieldwork [39], which according to several student teachers in this study are the most important source for species identification in schools and universities. These student teachers also received significantly better results in the identification test than the others. Previous research also indicates that there is a positive relationship between outdoor fieldwork and students' development of knowledge about and attitudes toward species [41-43]. When problem-based activities, learning-by-doing (hands-on activities), real-life learning and sensory engagement are included in field trips and fieldwork, they significantly improve students' interest, knowledge, attitudes and behavior, concerning sustainability $[37,38,72]$. Therefore, field trips and fieldwork should be encouraged as an integral part of education at all educational levels [50]. No matter if these are organized into natural environment (as most often in the Nordic countries) or into human-made environments, for example into botanical gardens [73,74], natural life parks [75], or aquariums [59], where the safety of the learners can be better guaranteed. The main point is to arrange field trips and fieldwork of high quality, which means that field trips and fieldwork are well planned and organized, the teachers take leading roles and have clear goals and high PCK, but where especially learners are highly active and engaged, substantially interacting with the environment and reporting their meaningful experiences [46]. Pre- and follow-up activities increase the value of learning during field trips and fieldwork $[59,76]$.

\subsection{Teachers' Role in Teaching and Learning Species and Species Identification}

How student teachers as future teachers look upon the teacher's role in their own learning affects the planning of their teaching $[19,20]$. The student teachers valued teachers highly regarding the learning of species and species identification, not only in teacher-centered methods, but also in cooperative and student-centered methods both outdoors and indoors. The student teachers made high demands on teachers' expertise in the form of solid subject knowledge, in-depth understanding of subjects and supervising skills for efficient teaching both outdoors and indoors. Similar findings have also been documented in, e.g., Janssen et al. [23] and McConnell et al. [30]. They asked for engaged teachers to motivate and activate the learners, to direct their observations into relevant things, to guide them during the whole process and to discuss (and sometimes also confirm) the results and possible consequences. In other words, this corresponds to teachers' PCK (pedagogical content knowledge; [24]), which is often used to explain the type of in-depth understanding needed to teach efficiently [30]. The student teachers' views confirm well previous research about teachers' professional development regarding their teaching about species and species identification in the context of biodiversity and sustainability education [25-29], but which still are lacking in most of the teacher education programs $[12,14,15]$.

According to previous research $[7,77,78]$, people's knowledge about nature, their interest in and experiences in nature influence their values and emotions regarding nature. Education promoting sustainability aspects, and thereby also education about species and species identification, is strongly based on values, attitudes and experiences [31,34,35]. The use of transformative learning as a quality of learning which touches and changes deep levels of values and attitudes through a process of realization 
and recognition [32] could therefore motivate teachers in more value-based teaching and learning about species and species identification. Deep engagement and understanding of the role of species in biodiversity and sustainability could thereby promote teachers' positive views on environmental issues and sustainability [33]. Good awareness of local common species makes teachers more willing to include field trips and fieldwork in their teaching [69].

\subsection{Media and the Internet for Teaching and Learning Species and Species Identification}

'Media' was also ticked by some student teachers among their three most important sources and there 'Internet' as their most important source of information about animal and plant species. They did not, however, specify what kind of material or resources they meant by 'Internet'. Neither was any significant difference found between the source used and the test results, but the men ticked the Internet significantly more often than the women. The Internet was not considered an optimal source for identification of unfamiliar species in Randler's study [62]. However, in this study several student teachers believed that they could find everything on the Internet and therefore considered it their most important source. Unfortunately, such beliefs, together with weak or no identification skills or knowledge about local species, can prevent teachers from including outdoor education into their teaching. It would therefore be interesting to investigate these student teachers further, asking them what and how they used the Internet to identify for example plants.

The Internet includes several web-based, interactive resources, which can be used for species identification. The use of web-based key characteristics of species [61] and Internet-based visual databases [57] are examples of the more specified use of the Internet. Another interactive multimedia dichotomous key [79] could be used for teaching and learning plant identification. There are, however, only preliminary results about the efficiency of these resources. Because the male student teachers valued the Internet more than the female student teachers, and because they were also more uninterested in plants, these Internet-based resources could be used as motivational factors, and as complementary to identification of species in authentic environments.

\subsection{Limitations}

The additional aim of this study was to analyze how well the student teachers' views were reflected in their results of the species identification test, i.e., how well the opinions corresponded to reality. This aim, however, has some limitations which make the interpretation of efficient teaching and learning methods only indicative, and further research is therefore recommended. Firstly, several of the student teachers answered what they believed was the most efficient method, not how they themselves had learned species. Secondly, it remained unclear how well they understood what a specific method was about and how it was used in practice. Although the student teachers had already taken the obligatory course or courses in biology or science, including theories of different kind of teaching methods, they may not have experienced them in practice. Thirdly, as we know, different teaching methods promote different learning styles, and the best way to learn something is very individual. An additional issue, not investigated in this study, is the situation where a learner's learning style does not match with a teacher's teaching style [80]. Fourthly, although the identification test involved photos of very common and well visualized species with their natural habitat as a background, the lack of the name of a species by some student teachers could only be temporary depending on the test situation and difficulties to suddenly remember the correct name.

\subsection{Summarizing Pedagogical Implications}

This study strengthens previous results about the importance of personal experiences and reallife issues in authentic environments for teaching and learning. Therefore, it is time to fulfill the requirements that teaching and learning of species and species identification should be involved as an integral part of teacher education programs for primary-school teachers. This would form the practical part of biodiversity and sustainability education. Time for practical training and teaching experiences 
should therefore be increased in teacher education programs in order to develop teachers' pedagogical content knowledge [26]. Because teacher education programs seldom include practical methods for fieldwork and other forms of outdoor education [54,55], teaching and learning of species and species identification through the most popular and efficient methods, outdoor experiential learning and outdoor project work, would fit very well as practical training of teaching. These methods could best be arranged during field trips and fieldwork of high quality, where living organisms and their habitats have the main role, completed with some functional web-based resources. High quality outdoor learning means well-planned curriculum-related activities, which include clear goals with pre- and follow-up phases [46]. Learners are expected to be highly active and engaged, and guided by supportive teachers, who have high PCK including knowledge about species and ecological principles as well as understanding of species role in biodiversity and sustainability. In this way successful experiences and meaningful activities could be transformed into the learners' increased curiosity and comprehension of species, biodiversity and sustainability.

Supplementary Materials: Supplementary Files are available online at http:/www.mdpi.com/2071-1050/11/19/ 5231/s1.

Author Contributions: Conceptualization, I.P., S.K., E.J., E.Y.-P. and C.P.; methodology, I.P., S.K., E.J., E.Y.-P. and C.P.; validation, I.P., S.K., E.J., E.Y.-P. and C.P.; formal analysis, I.P. and S.K.; investigation, I.P., S.K., E.J., E.Y.P. and C.P.; resources, I.P., S.K., E.J., E.Y.-P. and C.P.; data curation, I.P. and S.K.; writing-original draft preparation, I.P., S.K., E.J. and E.Y.-P.; writing—review and editing, I.P.; visualization, I.P. and S.K.; supervision, I.P.; project administration, I.P.; funding acquisition, I.P.

Funding: This research was funded by Finnish Högskolestiftelsen i Österbotten \& Svenska Kulturfonden.

Acknowledgments: Our thanks go to following colleagues for their help with collecting the material: Göran Abel, Susanne Antell, Jon Arve Husby, Ida Berg, John Magne Grindeland \& Hugo von Zeipel, and for the help with statistical analyses: Mikael Kalliokoski and Topi Myllynen.

Conflicts of Interest: The authors declare no conflicts of interest.

\section{References}

1. Kaasinen, A. Kasvilajien Tunnistaminen, Oppiminen ja Opettaminen Yleissivistävän Koulutuksen Näkökulmasta. Ph.D. Thesis, University of Helsinki, Helsinki, Finland, 2009.

2. Palmberg, I.; Jonsson, G.; Jeronen, E.; Yli-Panula, E. Blivande lärares uppfattningar och förståelse av baskunskap i ekologi i Danmark, Finland och Sverige. Nord. Stud. Sci. Educ. 2016, 12, 197-217. [CrossRef]

3. Randler, C. Teaching species identification: A prerequisite for learning biodiversity and understanding ecology. Eurasia J. Math. Sci. Technol. Educ. 2008, 4, 223-231. [CrossRef]

4. Lindemann-Matthies, P.; Bose, E. How many species are there? Public understanding and awareness of biodiversity in Switzerland. Hum. Ecol. 2008, 36, 731-742. [CrossRef]

5. Wandersee, J.H.; Schussler, E.E. Toward a Theory of Plant Blindness. Plant Sci. Bull. 2001, 47, 2-9.

6. Bickford, D.; Posa, M.R.C.; Qie, L.; Compos-Arceiz, A.; Kudovidanage, E.P. Science communication for biodiversity. Biol. Conserv. 2012, 151, 74-76. [CrossRef]

7. Palmberg, I.; Hermans, M.; Jeronen, E.; Kärkkäinen, S.; Persson, C.; Yli-Panula, E. Nordic student teachers' views on the importance of species and species identification. JSTE 2018, 29, 397-419. [CrossRef]

8. Finnish National Board of Education. The National Core Curriculum for Basic Education; Finnish National Board of Education: Helsinki, Finland, 2014.

9. Finnish National Board of Education. The National Core Curriculum for General Upper Secondary Schools; Finnish National Board of Education: Helsinki, Finland, 2015.

10. Royal Ministry of Education, Research and Church Affairs. Core Curriculum for Primary, Secondary and Adult Education in Norway; Royal Ministry of Education, Research and Church Affairs: Oslo, Norway, 2015; Available online: https://www.udir.no/globalassets/filer/lareplan/generell-del/core_curriculum_english.pdf (accessed on 18 December 2018). 
11. Swedish National Agency for Education. Curriculum for the Compulsory School, Preschool Class and the Recreation Centre; Swedish National Agency for Education: Stockholm, Sweden, 2011; Available online: https://www.skolverket.se/om-skolverket/publikationer/visa-enskild-publikation?_xurl_=http\%3A\%2F\% 2Fwww5.skolverket.se\%2Fwtpub\%2Fws\%2Fskolbok\%2Fwpubext\%2Ftrycksak\%2FBlob\%2Fpdf2687.pdf\% 3Fk\%3D2687 (accessed on 15 September 2018).

12. Evagorou, M.; Dillon, J.; Viiri, J.; Albe, V. Pre-service Science teacher preparation in Europe: Comparing pre-service teacher preparation programs in England, France, Finland and Cyprus. JSTE 2015, 26, 99-115. [CrossRef]

13. Falkenberg, T.; Babiuk, G. The status of education for sustainability in initial teacher education programmes: A Canadian case study. IJSHE 2014, 15, 418-430. [CrossRef]

14. Pathan, A.; Bröckl, M.; Oja, L.; Ahvenharju, S.; Raivio, T. Kansallisten Kestävää Kehitystä Edistävien Kasvatuksen ja Koulutuksen Strategioiden Toimeenpanon Arviointi; Gaia Consulting Oy: Helsinki, Finland, 2014; Available online: http://www.ym.fi/download/noname/\%7B7A0AC771-670C-48B8-B7F8-8FB0B173236F\%7D/78365 (accessed on 6 June 2018).

15. Wolff, L.A.; Sjöblom, P.; Hofman-Bergholm, M.; Palmberg, I. High performance education fails in sustainability?-A reflection on Finnish primary teacher education. Educ. Sci. 2017, 7, 32. [CrossRef]

16. Kvammen, P.I.; Munkebye, E. Artskunnskap Som Introduksjon Til Naturfag i Grunnskolelærerutdanningene. Nord. Stud. Sci. Educ. 2018, 14, 381-394. [CrossRef]

17. Lindemann-Matthies, P.; Constantinou, C.; Junge, X.; Köhler, K.; Mayer, J.; Nagel, U.; Raper, G.; Schule, D.; Kadji-Beltran, C. The integration of biodiversity education in the initial education of primary school teachers: Four comparative case studies from Europe. Environ. Educ. Res. 2009, 15, 17-37. [CrossRef]

18. Palmberg, I.; Berg, I.; Jeronen, E.; Kärkkäinen, S.; Norrgård-Sillanpää, P.; Persson, C.; Vilkonis, R.; Yli-Panula, E. Nordic-Baltic student teachers' identification of and interest in plant and animal species: The importance of species identification and biodiversity for sustainable development. JSTE 2015, 26, 549-571. [CrossRef]

19. Brundiers, K.; Wiek, A. Beyond interpersonal competence: Teaching and learning professional skills in sustainability. Educ. Sci. 2017, 7, 39. [CrossRef]

20. Pellikka, A.; Lutovac, S.; Kaasila, R. The nature of the relation between pre-service teachers' views of an ideal teacher and their positive memories of biology and geography teachers. Nord. Stud. Sci. Educ. 2018, 14, 82-94. [CrossRef]

21. Zoller, U. Research-based transformative science/STEM/STES/STESEP education for 'sustainability thinking': From teaching to 'know' to learning to 'think'. Sustainability 2015, 7, 4474-4491. [CrossRef]

22. Palmberg, I.; Hofman-Bergholm, M.; Jeronen, E.; Yli-Panula, E. Systems thinking for understanding sustainability? Nordic student teachers' views on the relationship between species identification, biodiversity and sustainable development. Educ. Sci. 2017, 7. [CrossRef]

23. Janssen, F.J.J.M.; Tigelaar, D.E.H.; Verloop, N. Developing biology lessons aimed at teaching for understanding: A domain-specific heuristic for student teachers. JSTE 2009, 20, 1-20. [CrossRef]

24. Shulman, L. Those who understand: Knowledge growth in teaching. Educ. Res. 1986, 15, 4-14. [CrossRef]

25. Chen, J.; Mensah, F.M. Teaching contexts that influence elementary preservice teachers' teacher and science teacher identity development. JSTE 2018, 29, 420-439. [CrossRef]

26. Großschedl, J.; Harms, U.; Kleickmann, T.; Glowinski, I. Preservice biology teachers' professional knowledge: Structure and learning opportunities. JSTE 2015, 26, 291-318. [CrossRef]

27. Holden, M.E.; Groulx, J.; Bloom, M.A.; Weinburgh, M.H. Assessing teacher self-efficacy through an outdoor professional development experience. Electr. J. Sci. Educ. 2011, 12, 1-25. Available online: http://ejse.southwestern.edu (accessed on 8 January 2018).

28. Hwang, H. The influence of the ecological contexts of teacher education on South Korean teacher educators' professional development. TTE 2014, 43, 1-14. [CrossRef]

29. Sandholtz, J.H.; Ringstaff, C. The influence of contextual factors on the sustainability of professional development outcomes. JSTE 2016, 27, 205-226. [CrossRef]

30. McConnell, T.J.; Parker, J.M.; Ebenhardt, J. Assessing teachers' science content knowledge: A strategy for assessing depth of understanding. JSTE 2013, 24, 717-743. [CrossRef]

31. Sipos, Y.; Battisti, B.; Grimm, K. Achieving transformative sustainability learning: Engaging head, hands and heart. IJSHE 2008, 9, 68-86. [CrossRef] 
32. Sterling, S. Transformative learning and sustainability: Sketching the conceptual ground. JLTHE 2011, 5, 17-33. Available online: http://dl.icdst.org/pdfs/files/0cd7b8bdb08951af53e5927e86938977.pdf (accessed on 8 January 2018).

33. Pugh, K.; Linnenbrink-Garcia, L.; Koskey, K.L.K.; Stewart, V.C.; Manzey, C. Motivation, learning, and transformative experience: A study of deep engagement in science. Sci. Educ. 2009, 94, 1-28. [CrossRef]

34. Bogner, F.X. Environmental values (2-MEV) and appreciation of nature. Sustainability 2018, 10. [CrossRef]

35. Lindemann-Matthies, P.; Constantinou, C.; Lehnert, H.J.; Nagel, U.; Raper, G.; Kadji-Beltran, C. Confidence and perceived competence of preservice teachers to implement biodiversity education in primary schools-Four comparative case studies from Europe. IJSE 2011, 33, 2247-2273. [CrossRef]

36. Kolb, D.A. Experiential Learning: Experiences as the Source of Learning and Development; Prentice-Hall: Englewood Cliffs, NJ, USA, 1984.

37. Liefländer, A.K.; Bogner, F.X. Educational impact on the relationship of environmental knowledge and attitudes. Environ. Educ. Res. 2018, 24, 611-624. [CrossRef]

38. Ballantyne, R.; Packer, J.M. Introducing a fifth pedagogy: Experience-based strategies for facilitating learning in natural environments. Environ. Educ. Res. 2009, 15, 243-262. [CrossRef]

39. Rickinson, M.; Dillon, J.; Teamey, K.; Morris, M.; Young Choi, M.; Sanders, D.; Benefield, P. A Review of Research on Outdoor Learning; National Foundation for Educational Research: Slough, UK, 2004; Available online: https://www.field-studies-council.org/media/268859/2004_a_review_of_research_on_ outdoor_learning.pdf (accessed on 8 January 2018).

40. Kopnina, H. Forsaking Nature? Contesting 'Biodiversity' through competing discourses of sustainability. JESD 2013, 7, 51-63. [CrossRef]

41. Fančovičová, J.; Prokop, P. Plants have a chance: Outdoor educational programmes alter students' knowledge and attitudes towards plants. Environ. Educ. Res. 2011, 17, 537-551. [CrossRef]

42. Killerman, W. Biology education in Germany: Research into the effectiveness of different methods. IJSE 1996, 18, 333-346. [CrossRef]

43. Lindemann-Matthies, P. 'Loveable' mammals and 'lifeless' plants: How children's interest in common local organisms can be enhanced through observation of nature. IJSE 2005, 27, 655-677. [CrossRef]

44. Morag, O.; Tal, T. Assessing learning in the outdoors with the field trip in natural environments (FiNE) framework. IJSE 2012, 34, 745-777. [CrossRef]

45. Scott, G.W.; Goulder, R.; Wheeler, P.; Scott, L.J.; Tobin, M.L.; Marsham, S. The value of fieldwork in Life and Environmental Sciences in the context of higher education: A case study in learning about biodiversity. J. Sci. Educ. Technol. 2012, 21, 11-21. [CrossRef]

46. Tal, T.; Alon, N.L.; Morag, O. Exemplary practices in field trips to natural environments. J. Res. Sci. Teach. 2014, 51, 430-461. [CrossRef]

47. Easton, E.; Gilburn, A. The field course effect: Gains in cognitive learning in undergraduate biology students following a field course. J. Biol. Educ. 2012, 46, 29-35. [CrossRef]

48. Randler, C.; Bogner, F. Cognitive achievements in identification skills. J. Biol. Educ. 2006, 40, 161-165. [CrossRef]

49. Stolpe, K.; Björklund, L. Seeing the wood for the trees: Applying the dual-memory system model to investigate expert teachers' observational skills in natural ecological learning environments. IJSE 2012, 34, 101-125. [CrossRef]

50. Behrendt, M.; Franklin, T. A review of research on school field trips and their value in education. IJESE 2014, 9, 235-245. [CrossRef]

51. Hamilton-Ekeke, J. Relative effectiveness of expository and field study methods of teaching on students' achievement in ecology. IJSE 2007, 20, 1869-1889. [CrossRef]

52. Magntorn, O.; Helldén, G. Reading nature from a 'bottom-up' perspective. J. Biol. Educ. 2007, 41, 68-75. [CrossRef]

53. Palmberg, I.; Kuru, J. Outdoor activities as a basis for environmental responsibility. J. Environ. Educ. 2000, 31, 32-36. [CrossRef]

54. Goulder, R.; Scott, G.W.; Scott, L.J. Students' perception of biology fieldwork: The example of students undertaking a preliminary year at a UK university. IJSE 2013, 35, 1385-1406. [CrossRef] 
55. Tal, T.; Morag, O. Reflective practice as a means for preparing to teach outdoors in an ecological garden. JSTE 2009, 20, 245-262. [CrossRef]

56. Tunnicliffe, S.D.; Reiss, M. Building model of the environment: How do children see animals. J. Biol. Educ. 1999, 33, 142-148. [CrossRef]

57. Kontkanen, J.; Kärkkäinen, S.; Dillon, P.; Hartikainen-Ahia, A.; Åhlberg, M. Collaborative processes in species identification using an internet-based taxonomic resource. IJSE 2016, 38, 96-115. [CrossRef]

58. Bebbington, A. The ability of A-level students to name plants. J. Biol. Educ. 2005, 39, 63-67. [CrossRef]

59. Pfeiffer, V.D.I.; Scheiter, K.; Kühl, T.; Gemballa, S. Learning how to identify species in a situated learning scenario: Using dynamic-static visualizations to prepare students for their visit to the aquarium. Eurasia J. Math. Sci. Technol. Educ. 2011, 7, 135-147. [CrossRef]

60. Francis, J.W. Use of Internet resources in the biology lecture classroom. Amer. Biol. Teach. 2000, 62, 90-93. [CrossRef]

61. Golick, D.A.; Heng-Moss, T.M.; Steckelberg, A.L.; Brooks, D.W.; Higley, L.G.; Fowler, D. Using web-based key character and classification instruction for teaching undergraduate students insect identification. J. Sci. Educ. Technol. 2013, 22, 509-521. [CrossRef]

62. Randler, C. Animal related activities as determinants of species knowledge. Eurasia J. Math. Sci. Technol. Educ. 2010, 6, 237-243. [CrossRef]

63. Elo, S.; Kääriäinen, M.; Kanste, O.; Pölkki, T.; Utriainen, K.; Kyngäs, H. Qualitative content analysis: A focus on trustworthiness. SAGE Open 2014, 1-10. [CrossRef]

64. Stevenson, K.T.; Peterson, M.N.; Carrier, S.J.; Strnad, R.L.; Bondell, H.D.; Kirby-Hathaway, T.; Moore, S.E. Role of significant life experiences in building environmental knowledge and behavior among middle school students. J. Environ. Educ. 2014, 45, 163-177. [CrossRef]

65. Beery, T.; Jørgensen, K.A. Children in nature: Sensory engagement and the experience of biodiversity. Environ. Educ. Res. 2018, 24, 13-25. [CrossRef]

66. McBride, B.B.; Brewer, C.A.; Berkowitz, A.R.; Borrie, W.T. Environmental literacy, ecological literacy, ecoliteracy: What do we mean and how did we get here? Ecosphere 2013, 4, 67. [CrossRef]

67. Yu, X. Is environment 'a city thing' in China? Rural-urban differences in environmental attitudes. J. Environ. Psychol. 2014, 38, 39-48. [CrossRef]

68. Braun, T.; Dierkes, P. Connecting students to nature: How intensity of nature experience and student age influence the success of outdoor education programmes. Environ. Educ. Res. 2017, 23, 937-949. [CrossRef]

69. Palmberg, I. Artkunskap och intresse för arter hos blivande lärare för grundskolan. Nord. Stud. Sci. Educ. 2012, 8, 244-257. [CrossRef]

70. Balas, B.; Momsen, J.L. Attention 'blinks' differently for plants and animals. CBE Life Sci. Educ. 2014, 13, 437-443. [CrossRef]

71. Hummel, E.; Randler, C. Living animals in the classroom: A meta-analysis on learning outcome and a treatment-control study focusing on knowledge and motivation. J. Sci. Educ. Technol. 2012, 21, 95-105. [CrossRef]

72. Kricsfalusy, V.; George, C.; Reed, M.G. Integrating problem- and project-based learning opportunities: Assessing outcomes of a field course in environment and sustainability. Environ. Educ. Res. 2018, 24, 593-610. [CrossRef]

73. Jagger, S.; Sperling, E.; Inwood, H. What's growing on here? Garden-based pedagogy in a concrete jungle. Environ. Educ. Res. 2016, 22, 271-287. [CrossRef]

74. Zelenika, I.; Moreau, T.; Lane, O.; Zhao, J. Sustainability education in a botanical garden promotes environmental knowledge, attitudes and willingness to act. Environ. Educ. Res. 2018. [CrossRef]

75. Cavas, B. Outdoor education in natural life park: An experience from Turkey. Sci. Educ. Int. 2011, 22, 152-160. Available online: http://www.icaseonline.net/sei/june2011/p6.pdf (accessed on 8 January 2019).

76. Subramaniam, K.; Asim, S.; Young Lee, E.; Koo, Y. Student teachers' images of science introduction in informal settings: A focus on field pedagogy. JSTE 2018, 29, 307-325. [CrossRef]

77. Cheng, J.C.H.; Monroe, M.C. Connection to nature: Children's affective attitude toward nature. Environ. Behav. 2012, 44, 31-49. [CrossRef] 
78. Duerden, M.D.; Witt, P.A. The impact of direct and indirect experiences on the development of environmental knowledge, attitudes, and behavior. J. Environ. Psychol. 2010, 30, 379-392. [CrossRef]

79. Jacquemart, A.L.; Lhoir, P.; Binard, F.; Descamps, C. An interactive multimedia dichotomous key for teaching plant identification. J. Biol. Educ. 2016, 50, 442-451. [CrossRef]

80. Chen, C.C.; Jones, K.T.; Moreland, K. Differences in learning styles. Responsibilities and leadership professional development. CPA J. 2014, 84, 46-51. [CrossRef] 